\title{
Can Auditors Be Independent? - \\ Experimental Evidence on the Effects of Client Type
}

\author{
Christopher Koch* \\ Assistant Professor \\ University of Mannheim, Schloss Ostflügel, 68131 Mannheim, Germany
}

\author{
Martin Weber \\ Professor of Finance and Banking \\ University of Mannheim, L 5, 2, 68131 Mannheim, Germany \\ Jens Wüstemann \\ Professor of Accounting and Auditing \\ University of Mannheim, Schloss Ostflügel, 68131 Mannheim, Germany
}

\section{August 2011}

\begin{abstract}
Acknowledgments
The comments of Jannis Bischof, Thomas Carrington, Holger Daske, Aasmund Eilifsen (discussant), Michael Favere-Marchesi (discussant), Don Finn (discussant), Anna Gold, Frank Hartmann, Christopher Humphrey, Kathryn Kadous (discussant), Hansrudi Lenz, Jason MacGregor, Ernst Maug, Martin Richter, Steven Salterio, Ulrike Stefani (discussant), Jeroen Suijs, Hun-Tong Tan, and workshop participants at the Erasmus University of Rotterdam and the University of Mannheim, the 2007 Symposium of the European Auditing Research Network in Aarhus, Denmark, the 2008 Auditing Section Midyear Conference in Austin, TX, the 2008 Annual Congress of the European Accounting Association in Rotterdam, the Netherlands, the 2008 Annual Meeting of the German Academic Association for Business Research in Berlin, Germany, the UF 2009 International Conference on Assurance and Governance in Gainesville, FL, the 2009 Annual Conference of the Accounting Section of the German Academic Association for Business Research (Best Paper Award) are greatly appreciated. Financial support from the German Research Foundation (DFG Grant SFB504) is acknowledged. Finally, we thank two of the Big 4 audit firms for supporting us, and the participants for their time and effort in completing the research study.
\end{abstract}

*Corresponding author. Tel.: +49 621181 2359, Fax:+49 621181 1694,

E-Mail: ckoch@bwl.uni-mannheim.de. 


\section{Can Auditors Be Independent? - Experimental Evidence on the Effects of Client Type}

Abstract Recent regulatory initiatives stress that an independent oversight board, rather than the management board, should be the client of the auditor. In an experiment, we test whether the type of client affects auditors' independence. Unique features of the German institutional setting enable us to realistically vary the type of auditors' client as our treatment variable: we portray the client either as the management preferring aggressive accounting or the oversight board preferring conservative accounting. We measure auditors' perceived client retention incentives and accountability pressure in a post-experiment questionnaire to capture potential threats to independence. We find that the type of auditors' client affects auditors' behaviour contingent on the degree of the perceived threats to independence. Our findings imply that both client retention incentives and accountability pressure represent distinctive threats to auditors' independence and that the effectiveness of an oversight board in enhancing auditors' independence depends on the underlying threat.

JEL: C90, K22, M42

Keywords: auditor independence; accountability pressure; client retention incentives, oversight board, behavioural experiment

Data Availability: Data are available from the authors on request. 


\section{Introduction}

In recent years, regulators worldwide have stressed that an independent oversight board, rather than the management board, should be the client of the auditor. ${ }^{1}$ In the U.S., the Sarbanes-Oxley Act of 2002 (SOX) requires that each listed company must establish an independent audit committee to serve as an oversight board that is directly responsible for the appointment, compensation, and oversight of the auditor (Section 301). Pre-SOX, the management was in many cases effectively in charge of nominating the auditor and negotiating audit fees (SEC, 2003; Mayhew and Pike, 2004). The European Directive on statutory audits of 2006 states that each public-interest entity must have an audit committee responsible for monitoring the work of the auditor, reviewing auditors' independence, and issuing recommendations on auditors' appointments (European Union, 2006). This directive must be adopted as law by the member states. In the U.K., the establishment of an audit committee is now mandated by the Disclosure Rules and Transparency Rules (Financial Services Authority, 2009), but previously only recommended by the Combined Code on Corporate Governance (Financial Reporting Council, 2008). In the German two-tier system, the supervisory board, which is an oversight board that is institutionally separated from the management board, has been responsible for monitoring the auditor and for issuing recommendations on auditor appointments since 1998 (German Federal Parliament, 1998; Gassen and Skaife, 2009).

In an experiment with professional auditors, we compare auditors' behaviour under two client type conditions that differ from each other in both client identity and client preferences. This means that the client is either the management preferring aggressive accounting or the oversight board preferring conservative accounting. We describe the management as preferring aggressive accounting, which we define as income-increasing, given that regulators are especially concerned about auditor independence in such a scenario (SEC, 2003). In contrast, we describe the supervisory board as preferring conservative 
accounting, which we define as income-decreasing. This preference structure reflects reality, because although oversight boards should be independent, at the same time they face a high risk of litigation, especially in cases where earnings are overstated (Hoi et al., 2007). This joint variation of client identity and client preferences contrasts the two client types that are most interesting in the context of auditor independence regulation. Doing so provides evidence of whether auditors are really more objective when they are "hired, evaluated and, if necessary, terminated by the audit committee" (SEC 2003) and whether it was justified to argue that "it strains imagination to see the auditor as independent of the management" if the management hires the auditor (Abdel-Khalik, 2002: 100).

To reconstruct both client types in a realistic manner, we use the German institutional setting. There are about 20,000 companies in Germany with statutory audits under which auditors' clients can be either the management or the supervisory board, depending on the company's decision on the formation of a supervisory board and the company's bylaws. These are private limited companies with more than 50 employees, which means that they are large enough that they are obliged to be audited, but less than 500 employees, which gives them the choice of whether or not to create a supervisory board. ${ }^{2}$ The legal threshold of 500 employees ensures that a researcher would not expect to find any difference in the type of firm between companies that are slightly below or above that threshold, making the presence of a supervisory board as auditors' client largely an exogenous factor.

Further, we test whether the type of client influences auditors' reactions to two of the main threats to their independence, client retention incentives and accountability pressure (Bazerman et al., 2006). Client retention incentives can arise when an auditor has financial incentives to become lenient towards the management in order to retain their mandate (Magee and Tseng, 1990). Transferring the decision-making power on auditors' retention from the management to the audit committee should mitigate this incentive (Lee and $\mathrm{Gu}, 1998$ ). The other threat, accountability pressure, arises when auditors who feel accountable towards the 
management may be at risk of adopting the preferences of the management in terms of their own judgment (Bazerman et al., 1997; Bazerman et al., 2002). Such behaviour can occur when auditors unconsciously try to avoid conflict with parties to whom they feel accountable (Tetlock, 1985). In its role as an auditor's client, an oversight board might ensure that auditors feel less accountable to the management by "providing a forum separate from management in which auditors $[\ldots]$ can candidly discuss concerns" (SEC, 2003). To explore how a change in client type affects auditors' reactions to potential threats to auditors' independence, we use a post-experiment questionnaire to measure auditors' perceived client retention incentives and accountability pressure.

The experimental task consists of the evaluation of two accounting cases. The primary dependent variable is the audit opinion. We classify auditors' independence as being at risk when auditors are willing to issue an unqualified opinion for a financial statement that reflects the management's preference for aggressive accounting. This classification is consistent with Antle (1984), who suggests as a measure of auditors' independence the willingness of auditors to follow the preferences of the manager. Our focus on auditors' ability to be unbiased in their judgments relates especially to auditors' objectivity as one dimension of auditor independence (Taylor et al., 2003).

We find that auditors' propensity to issue unqualified audit opinions is not affected by the type of client which indicates that auditors are generally able to maintain independence from the client. We further investigate the interaction effects of auditors' client type and auditors' reaction to potential threats to auditor independence. Our results show that auditors with high client retention incentives are more willing to accept the management's preferred accounting method when they are employed by the management. However, auditors are less likely to do so when they are employed by a supervisory board. Furthermore, we find that perceived accountability pressure is a statistically significant effect: lower-rank auditors are more likely to issue unqualified audit opinions when they feel under high accountability 
pressure for both types of client. These findings imply that on the one hand, an auditor that has an oversight board as its client seems to change the auditors' reaction to financial incentives. On the other hand, this shift in the type of client does not seem to be effective in influencing auditors' reaction to accountability pressure.

Our experimental study on the effects of client type contributes to prior literature on auditor independence that has usually considered management as potential clients of auditors (e.g., Hackenbrack and Nelson, 1996; Kadous et al., 2003; Blay, 2005). Further, experiments with alternative parties as auditors' clients have only been designed in experiments with students as participants (Mayhew and Pike, 2004; Kadous et al., 2003: fn. 19). We also investigate whether client retention incentives and accountability pressure represent two distinctive threats to auditors' independence. This test addresses the research gaps identified by Bamber and Iyer (2007: 2), that “(p)rior accounting research does not address the effect of social forces or incentives on auditors' objectivity", and by Bonner (2007: 220), that it is "crucial to attempt to separate the effects of social $[\ldots]$ consequences from the effects of monetary consequences when studying accountability". Prior research has investigated accountability pressure, but mainly in the context of hierarchical relationships within the audit firm and with limited attempts to separate the effects of financial incentives and accountability pressure (for a review see DeZoort and Lord, 1997).

Our study adds to archival research by showing that strong audit committees are associated with higher financial reporting quality and, particularly, with higher audit quality (for reviews see Pomeroy and Thornton, 2008; Carcello et al., 2011). Although the archival literature identifies important determinants for audit committee effectiveness, it provides limited insights into the process how audit committee members influence auditor behaviour (Gendron et al., 2004). We investigate how oversight boards affect auditor behaviour via its impact on the effects of auditors' accountability pressure and client retention incentives. Further, our experimental design avoids issues of endogeneity arising from the selection of 
high quality auditors by high quality audit committees (e.g., Chen and Jian, 2007) and enables the use of more direct proxies for auditor independence (e.g., Dopuch et al., 2001).

The paper proceeds as follows. In Section 2 we develop our hypotheses by drawing from theory and prior auditing literature. In Section 3 we describe the experimental design, and in Section 4 we report the results. Section 5 concludes, and also addresses limitations.

\section{Hypotheses development}

\subsection{Distinguishing client retention incentives and accountability pressure}

Accountability pressure and client retention incentives are often intertwined. For example, the importance of the client enhances both client retention incentives and accountability pressure (Lerner and Tetlock, 1999; Bamber and Iyer, 2007). But accountability pressure is distinct from client retention incentives, since it can also arise without the presence of monetary incentives, emerging purely from the desire to avoid conflict (Tetlock, 1985). We wish to distinguish between these two potential threats to auditors' independence for two reasons. First, although auditors might be aware that they are influenced in their judgment by financial considerations, they may not be aware of the effects of accountability pressure. (Bazerman et al., 2002). Second, measures to ensure auditors' independence might differ in their effectiveness, depending on the underlying threat to be remedied (Bamber and Iyer, 2007). For example, Moore et al. (2006) argue that in the Sarbanes-Oxley Act, the prohibition of certain non-audit services might have been effective in counteracting client retention incentives, but auditors' independence would remain endangered due to accountability pressure. Our study, which varies the nature of the auditor-client relationship, we provide a natural setting for distinguishing between the effects of accountability pressure and financial incentives. 


\subsection{Client retention incentives and client type}

Economic theory suggests that the effects of client retention incentives on auditors' independence depend on who the auditor's clients are. When auditors' clients are the management, then client retention incentives can pose the danger that auditors become lenient in their audit decisions and are more willing to accept the management's preferred accounting method than they should be (Magee and Tseng, 1990). But when auditors' clients are oversight boards whose incentives are aligned with those of the investors, then the auditors' independence can be enhanced and the auditors are less likely to accept an aggressive accounting method preferred by the management (Lee and Gu, 1998). The reason for these differing effects of different client types on auditors' behaviour is that if their clients are independent oversight boards, then auditors no longer have to fear being replaced when they disagree with the management (Dye, 1991).

Prior experimental studies find that auditors' independence is at risk when auditors are hired by the management, at least when client retention incentives are high. For example, auditors are more willing to accept the accounting method proposed by the management when the risk of losing the client is high (e.g., Blay, 2005), when the client is important (e.g., Chang and Hwang, 2003), when the auditor's compensation scheme rewards client retention (e.g., Trompeter, 1994), or when the client represents future business opportunities (e.g., Moreno and Bhattacharjee, 2003). The potential negative effects of client retention incentives on auditors' independence are especially likely to occur when the auditor is highly committed to retaining the client (Kadous et al., 2003). Experiments with auditors have not investigated the effects of oversight boards as auditors' clients yet. An abstract economic experiment with students as subjects suggests that it can have positive effects (Mayhew and Pike, 2004).

Our first hypothesis investigates whether the type of client an auditor has affects auditors' reactions to potential threats to their independent judgment. Based on the theory and experimental findings discussed above, we expect client type and client retention incentives to 
have interactive effects. That is, we expect that a high level of client retention incentives can endanger an auditor's independence when the auditor's client is the management, but that high client retention incentives can enhance an auditor's independence when the client is an oversight board.

H1: The effects of client retention incentives on auditors' behaviour depend on the type of client: Auditors with high client retention incentives are more likely to issue an unqualified opinion if their clients are management bodies that prefer aggressive accounting, and less likely to do so if their clients are supervisory boards that prefer conservative accounting.

\subsection{Accountability pressure and client type}

Another important threat to auditors' independence is accountability pressure. Accountability pressure arises when a judgment or a decision has to be justified towards another party that the auditor considers important. When the view of that other party is known, people unintentionally adjust their own thinking towards the preferences of that party (Tetlock, 1985). This adjustment happens, because people seek the social approval of others (Schlenker, 1980) and attempt unconsciously to adopt a socially acceptable and compliant position (Lerner and Tetlock, 1999). This judgment process is called the acceptability heuristic (Tetlock, 1985).

Accountability is a multiple-source phenomenon. In auditing, important other parties to whom auditors must justify their opinion are the auditors' clients and superiors (Gibbins and Newton, 1994). Prior auditing research has focused on accountability pressure from superiors acting as reviewers within the audit firm (DeZoort and Lord, 1997). These studies show that the preferences of the superior can influence the behaviour of the subordinate auditor (e.g., Peecher, 1996). They also demonstrate that contextual features matter. For 
example, the impact of accountability is stronger in a scenario where participants expect a face-to-face review compared to an electronic review (e.g., Wilks, 2002).

Prior research on the effects of accountability pressure experienced by auditors towards their clients is limited. Accountability theory suggests that when management is the auditor's client, there is a risk that auditors will unconsciously adopt the preferences of the management (Bazerman et al., 1997), because the antecedents for the acceptability heuristic are fulfilled: management acting as the client represents an important other party for the auditor; auditors have to justify their audit judgments and decisions to management (Gibbins et al., 2001; Sanchez et al., 2007); and auditors know management's preferred accounting method from the preliminary financial statements. Bamber and Iyer (2007) study accountability in a field-based analysis, and find that auditors who identify more strongly with management are more likely to acquiesce to the client-preferred treatment norms. One of the very rare studies that directly tests the source of accountability pressure is Buchman et al. (1996). In their experiment, these authors use three condition in which auditors are accountable to no one, to the management, or to the audit partner. They find weak evidence that auditors who are accountable towards the management use the acceptability heuristic.

One important research question is whether audit committees that hold the auditor accountable are able to change the influence of management. Regulators hope that the oversight board, in acting as an auditor's client, can provide "a forum separate from management in which auditors [...] can candidly discuss concerns", thereby ensuring "that the outside auditors, through their own review, objectively assess the company's financial reporting practices" (SEC, 2003). This effect is consistent with the acceptability heuristic under the premise that auditors consider the oversight board as an important party to whom they have to justify their judgments and decisions (e.g., ISA 260, SAS 114, SAS 115) and whose preferences they know, e.g., from discussions during the planning of the audit or from prior year audits. Our study addresses this research question by making use of the German 
institutional setting. Investigating the effects of an oversight board is important given the context-dependence of accountability (Gibbins and Newton, 1994: 165). Further, it enables the examination of the effects of accountability on the behaviour of highly experienced auditors, since the pressure felt towards the client will probably be higher for them than the pressure felt towards a reviewer within the firm (Gibbins and Newton, 1994: 168).

Based on the accountability theory, we formulate the following hypothesis, which predicts an interactive effect of accountability pressure and client type:

H2: The effects of accountability pressure on auditors' behaviour depend on the type of client: Auditors who feel that they are under high accountability pressures are more likely to issue an unqualified opinion if their clients are management bodies that prefer aggressive accounting, but are less likely to do so if their clients are supervisory boards that prefer conservative accounting.

\section{Research design}

\subsection{Participants}

Two of the international Big 4 audit firms agreed to support our experiment. At one audit firm, auditors participated in the experiment at the end of the first day of a two-day training program designed for all levels of experience. This training program was held in three different regions in Germany. At the other audit firm, the experiment was conducted prior to a German nationwide partner/manager meeting, and the participants were asked to sign up for the experiment before the meeting.

Our sample comprised 72 audit practitioners representing all levels of experience participated. ${ }^{3}$ Table 1 shows that the 21 staff auditors and the 18 audit seniors of our study have similar years of experience (medians are three and four years, respectively), and that the 
18 experienced audit managers and 12 audit partner are highly experienced (medians are 11.5 and 16 years, respectively). The variation in rank and years of experience within the experiment enables us to make supplemental explorations on the mitigating effects of experience.

Our experimental tasks make a good fit for all experience levels. Staff and senior auditors regularly perform audit procedures on the appropriateness of allowance for bad debt and the valuation of provisions, and audit managers and partners review these procedures (Abdolmohammadi, 1999). The tasks include an indication of the audit opinion that will be issued. Although audit managers and partners make the final decision concerning the audit report disclosure, lower-rank auditors influence this decision (Ricchiute, 1999). Hence, auditing research regularly regards it as appropriate to ask staff and senior auditors about their audit report decision (e.g., Nelson and Kinney, 1997; Joe, 2003). To reflect the higher familiarity of managers and partners with the audit opinion decision, we conduct additionally subsample analyses that focus on the behaviour of manager and partners. We note that for our sample, this subsample construction is almost equivalent to a split by auditors' years of experience, since the years of experience of audit managers and partners hardly overlap with those of staff and senior auditors. Table 1 illustrates this equivalency.

\section{--- Insert Table 1 here ---}

\subsection{Procedure}

The format of all sessions was the same. To ensure that the experiment would proceed in a controlled manner, one of the authors was present in each session together with research assistants. Figure 1 shows the outline of the research procedure, which consisted of three parts. In the first part, we randomly determined for each auditor whether the client in question was the management or the supervisory board. In the first part we describe the firm characteristics, 
client type, and the audit appointment process and pose framing questions. We also told the auditors that about one in eight would be randomly selected for a ten-minute simulated meeting with the client after the experiment. We randomly selected auditors for this meeting after each auditor had handed in the test materials. Then, each auditor was given the task of evaluating two ambiguous accounting cases. In the third part, the auditors filled out questionnaires that included questions related to their perceived client retention incentives, their feelings of accountability pressure, and their level of experience.

\section{--- Insert Figure 1 here ---}

\subsection{Task and dependent variables}

Auditors evaluated their two accounting case studies under German GAAP. We use two case studies instead of one to enhance the generalizability of the results. We note that analyzing the two case studies individually yields results that are qualitatively similar to the combined results reported below. We randomly varied across participants the order in which the cases were presented. The first case covered the measurement of provisions for warranties and the second case covered allowances for bad debt. These accounting issues have often been considered in previous auditing research and are relevant to auditor-client meetings, since they affect reported earnings (Gibbins et al., 2001). We designed the cases to be ambiguous, since prior research suggests that auditors' independence is most strongly affected by client retention incentives (Hackenbrack and Nelson, 1996; Salterio and Koonce, 1997) and accountability pressure (Boiney et al., 1997) when no clear guidelines exist. We developed the design of experiment in collaboration with audit practitioners. We pretested the materials in one mail-based testing, using ten audit practitioners as participants, and in two in-class sessions with students as participants. 
At the beginning of each case study, we presented the accounting method used by the audited company in its preliminary financial statement. In line with the preferences of the management, we constructed very aggressive accounting methods. Then we introduced five pieces of evidence stepwise, thus simulating the audit process in which the auditor gathers audit evidence step by step. This procedure also made it possible for us to elicit auditors' evaluations of each piece of evidence immediately after it was presented, and it ensured that the participants were motivated to consider all pieces of evidence carefully. The auditors judged the conformity of each company's accounting method with GAAP, chose the appropriate measurement amount, and decided what audit opinion to issue if the audited firm was not willing to record any adjustments. Table 2 provides the details on the eliciting and coding of all dependent variables.

Our primary dependent variable is the audit opinion, since issuing the correct audit opinion is the auditor's primary task. Furthermore, we assume that the client is especially concerned about receiving an unqualified opinion when making the decision regarding whether to retain the auditor (e.g., DeAngelo, 1981), which is also why auditors experience the strongest need for justification and high accountability pressure for this decision (Buchman et al., 1996; Turner, 2001).

We classify audit opinion as a binary variable. We code unqualified opinions as one and both qualified and adverse opinions as zero. Our results hold when classifying audit opinion as an ordinal variable by coding unqualified opinions as two, qualified opinions as one and adverse opinions as zero, and when classifying audit opinion as a continuous variable. In our analyses, we use logistic regressions by pooling all data. This results in a total of 144 observations from 72 auditors. The main logistic regression analyses include 132 observations from 67 auditors due to missing data (3x audit opinion, 6x hierarchy level, $2 x$ accountability pressure, $8 \mathrm{x}$ client retention incentives; multiple missing data items for some observations). The results of these analyses hold when including subject as a random effect. 


\subsection{Treatment variable: client type}

We randomly assigned the type of client. Thirty-seven subjects were accountable to the management and 35 auditors answered to the supervisory board. We established the accountability relationship by informing auditors about the background of the audit engagement. The auditors were told that either the management or the supervisory board had hired them, what their client's preferences were, and that a meeting with their client would take place at the end of the session, at which time the auditor should be ready to defend his or her audit judgments and decisions. After auditors had received this information, we asked them to characterize this scenario and to describe similar scenarios that they themselves had experienced. These framing questions were intended to ensure that auditors internalized the experimental setting. Furthermore, participants were reminded of their client's identity by our repeating throughout the experimental tasks that auditors' responses will be forwarded to either the management or the supervisory board.

The uniqueness of the German institutional setting made it possible for us to realistically vary the auditors' clients. To avoid confounding demand effects, a realistic description is essential in an experiment with professional auditors. In Germany, as in many code law countries, a two-tier board structure is in place for limited companies (e.g., Schöndube-Pirchegger and Schöndube, 2010). ${ }^{4} \mathrm{~A}$ two-tier board structure means that the supervisory board (Aufsichtsrat) and the management (Vorstand/Geschäftsführung) are two distinct bodies of the corporation (e.g., Leuz and Wüstemann, 2004). While the management governs the company, the supervisory board controls the management. Under the Corporate Control and Transparency Act of 1998, the supervisory board became generally responsible for nominating the auditor for election at the annual shareholder meeting, appointing the 
auditor, and negotiating the compensation terms (Gassen and Skaife, 2009). Furthermore, the supervisory board is now the primary recipient of auditor's internal long-form audit report (Leuz and Wüstemann, 2004). However, the management is still responsible for appointing the auditor in private limited companies with fewer than 500 employees that are not required to have a supervisory board (Theisen, 2007). ${ }^{5}$ Because all corporations with more than 50 but fewer than 500 employees are required by law to be audited ${ }^{6}$, either the management or the supervisory board can be in charge of nominating the statutory auditor. Furthermore, when comparing companies that are slightly above or below that threshold, the legal threshold of 500 employees makes the presence of a supervisory board as auditors' client largely an exogenous factor.

Concerning auditors' appointment, in Germany, in the other members states of the European Union, and in the U.S., the institutional settings are comparable in many ways. The German Corporate Control and Transparency Act of stressed the role of the supervisory board as auditors' client, and the U.S. Sarbanes-Oxley Act of 2002 and the European Directive on statutory audits of 2006 did the same with the audit committee. However, it is possible to vary the auditors' client within the German institutional setting in a more realistic and more clearcut way than, for example, within the U.S. institutional setting. German federal law and corporate bylaws give the management the explicit authority to be auditors' client for a large number of companies with mandatory audits, but in statutory audits in the U.S., the management cannot formally be the auditor's client. Only informally can management be the key decision-maker in determining auditors' appointment at some companies in the U.S. (Cohen et al., 2010).

In our experiment, the management prefers aggressive reporting. In the description, we state that management would miss earnings forecasts, forfeit bonus payments, and risk being dismissed if it opts for a more conservative accounting method. We choose this characterization of the management, because we want to simulate the perspective of 
regulators who are concerned that auditors' independence is at risk when they face management with strong incentives to increase earnings (SEC, 2003). This assumption about the incentives is also in line with empirical findings that management regularly engages in earnings management (Nelson et al., 2002).

We describe the supervisory board as preferring conservative reporting. In the description, we note that the members face litigation risk if there is aggressive reporting (Lederer, 2006) and that to ensure the viability of the company, the members wish to restrict possibilities for future dividend payouts (Leuz and Wüstemann, 2004). In reality, although oversight board members are supposed to be independent, to reduce litigation risk they have incentives to favour conservative reporting (Hoi et al., 2007). Therefore, oversight board members are likely to have preferences that maintain their financial reporting integrity (Pomeroy, 2010).

The way we use client types varies both client identity and client preferences. This joint variation is intended to reflect reality, and contrasts the two client types that are most interesting in the context of auditor independence regulation. One of our important aims is to ensure the statistical power of experiment our research by increasing the strength of the treatment effect (Shadish et al., 2002: 47). We expect that joint variation of both constructs increases the overall strength of the treatment, since the resulting conditions portray the two client types most opposed to each other. Doing so provides a test that is statistically and sufficiently powerful on whether client type has any effect on auditor behaviour, but it does not allow for a distinction between client identity or client preferences as potential sources of such an effect. Thus, we do not separately test for the effects of client identity and client preferences due to constraints in the number of highly experienced participants. 
3.5. Measured independent variables: client retention incentives, accountability pressure, and auditors' rank

As described above, client retention incentives and accountability pressure are interrelated. Nevertheless, it is important to distinguish between these two potential threats to auditors' independence, since the effectiveness of remedies for mitigating these threats might depend on the source of the threats. We follow Bonner's (2007: 220) recommendation that postexperiment questions be used to distinguish between the two different threats (see Table 3 for details on the measured and treatment variables).

Client retention incentives depend on the importance of the client (DeAngelo, 1981) and the likelihood that the client will switch the audit firm in case of disagreements (Dye, 1991; Lennox, 2000). We construct a setting with high client retention incentives. We describe the client as being very important, because it contributes one-fourth of the total audit fees of the local office. We describe the risk of dismissal as being very high because the client has demonstrated in the past that it is willing to switch auditors if there is any disagreement. In a post-experiment questionnaire, we elicit a proxy for perceived client retention incentives by aggregating auditors' evaluation of two questions. First, we ask auditors how likely they consider the threat of being dismissed if there is client-auditor dissent. Second, we ask auditors how likely they consider that other auditors will make concessions in judgment based on this threat.

In our study, we create accountability pressure by requiring auditors to justify their decisions to the clients, both in written form and in an announced face-to-face meeting (Brazel et al., 2004; DeZoort et al., 2006). We ensure that auditors are aware of the justification requirement by repeating it before each judgment and decision task. In our postexperiment questionnaire, we asked auditors to what extent they would insist on maintaining their audit judgments to their colleagues, and then asked them how strong their desire was to avoid conflict with their clients in the upcoming meetings. The first question measures 
subjects' perceived personal responsibility as "responsibility is a necessary component of the process of holding people accountable for their conduct" (Schlenker et al., 1994: 634). The second questions measures conflict avoidance as another concept underlying accountability, since subjects with a high degree of desire to avoid conflict have been found to be especially sensitive to accountability pressure (Chen et al., 1996; Lerner and Tetlock, 1999). The aggregate answer to these two questions is our proxy for perceived accountability pressure.

--- Insert Table 3 here ---

\subsection{Relation between independent variables}

In Table 4 we examine the relation between the independent variables. First, because we are interested in investigating whether our constructs for client retention incentives and accountability pressure measure different aspects. We find that client retention incentives and accountability pressure are not significantly correlated in the full sample $(\rho=0.11 ; p=0.386)$, which suggests that the two constructs are distinct from each other. Second, our analysis serves as a check on whether client type or auditors' rank has unanticipated effects on the subjective measured variables. We find that client type has no significant effects on these variables. This finding is also supported by the descriptive statistics, which do not indicate major differences across client type.

--- Insert Table 4 here ---

\section{Results}

\subsection{Descriptive statistics and effects of client type}

Table 5 indicates that auditors perceive managements' accounting method choices to be overly aggressive. Auditors issue unqualified opinion only in about half of the time (mean 
$(\mathrm{SD})=0.47(0.5))$ and require, on average, write-downs of $€ 39.8 \mathrm{M}(\mathrm{SD}=€ 36.3 \mathrm{M})$. Further, they evaluate managements' accounting method choices to be not fully in conformance with GAAP (mean $(\mathrm{SD})=4.25(3.16)$ ), and also do not consider the pieces of audit evidence as supporting these choices (mean $(\mathrm{SD})=-2.76(8.48)$ ). These descriptive results also hold for the subsample of managers and partners, with the exception that these auditors are even more sceptical in their evaluation of evidence.

In Table 5, the analysis of the overall effect of client type on auditors' behaviour reveals no indications that auditors generally acquiesce to clients' preferences in their audit opinions decisions. Auditors who are employed by a management that favours aggressive accounting issue unqualified opinions in $49 \%$ of all cases, and auditors employed by supervisory boards that prefer conservative accounting issue unqualified opinions in $45 \%$ of all cases. We find no significant difference for the measurement decision on the amount of necessary adjustments (€41.3M compared to $-€ 38.3 \mathrm{M})$. However, we find that auditors are influenced by client type in judgment tasks. Auditors who are employed by management consider audit evidence more often in contradiction to the aggressive accounting method chosen in the financial statements, and they judge the financial statements conformity with German GAAP to be lower. Again, our results hold for the subsample of managers and partners except for a qualitatively similar, but nonsignificant difference in the judgment of GAAP conformance by client type.

--- Insert Table 5 here ---

We use a structural-equation-based path analysis to further investigate the effects of client type on auditors' judgment and their subsequent audit decision. Figure 2 presents the model with audit evidence evaluation as the judgment task and audit opinion choice as the decision task. The goodness of fit of the model is excellent (chi-square $=0.007,3 \mathrm{df}, p=1$ ). 
The results for the full sample of all observations show, first of all, an indirect effect of client on auditors' decisions via auditors' judgement. Auditors hired by a management with preferences for aggressive reporting are more sceptical towards the presented audit evidence (Link 1, Coef. $=-5.71, p<0.001$ ) which, in turn, reduces the auditor's propensity to issue an unqualified audit opinion (Link 2; Coef. $=0.018, p<0.001$ ). But client type has also a direct effect (Link 3, Coef. $=0.14, p=0.077$ ), which means that auditors employed by management are more likely to issue an unqualified opinion. The indirect effect (Links 1 and 2, Coef. = $0.1, p<0.001)$ and the direct effect (Link 3) neutralize each other, leading to nonsignificant total effect (Coef. $=0.04, p=0.609)$. Figure 2 shows that the results are qualitatively similar for the subsample of managers and partners.

These results can be explained with Turner's (2001) theory. According to Turner, the researcher has to distinguish between belief and action tasks when investigating the effects of motivational factors. Turner defines belief tasks as judgments that do not directly affect the audit outcome, e.g., the evaluation of audit evidence; action tasks refer to decisions that directly affect the audit outcome, e.g., the audit opinion decision. In either belief or judgment tasks, auditors are concerned about quality. This theory explains why auditors in our test are sceptical about their clients' preferences when evaluating evidence, since one dimension of audit quality is professional scepticism (Gramling, 1999). ${ }^{7}$ The theory further states that people experience feelings of responsibility most intimately for action or decision tasks (Tversky, 1972; Turner, 2001). These feelings intensify accountability pressure (Lerner and Tetlock, 1999), and potentially underlie the observed direct effect of client type.

In our scenario the audit opinion choice is the most important audit decision. Consistent with the reasoning that accountability pressure is highest for this variable, we find that substituting the measurement decision for the audit opinion decision in the model reported in Figure 2 yields slightly weaker direct effects of client type (untabulated). Further, the main and interaction effects of the measured independent variables are not significant for 
measurement and the other dependent variables (untabulated). Thus, we concentrate on the audit opinion as the dependent variable in this and the following analyses.

--- Insert Figure 2 here ---

\subsection{Effects of client retention incentives and client type}

In H1 we predicted that the influence of client type on auditors' decision to accept an aggressive accounting method would depend on the level of auditors' client retention incentives. In Table 6 we test H1 in a logistic regression analysis. Our regression analysis includes a dummy variable for the case study as control. The significance of this variable indicates that auditors are more likely to issue an unqualified opinion for Case Study 1 (provisions for warranties) than for Case Study 2 (accounts receivable). However, all interaction effects between a variable for the case version and any of the independent variables are not significant, indicating that behavioural effects in response to the independent variables generalize across both cases (untabulated).

Consistent with our expectation, the interaction between client type and client retention incentives is marginally significant $(p=0.083$; see Table 6 and Figure 3$)$. This interaction effect indicates that auditors with high client retention incentives are more likely to issue unqualified audit opinions when their clients are management bodies that favour aggressive accounting. It implies that giving supervisory boards that favour conservative accounting the authority to hire the auditor can encourage that auditor to be more critical in its decision to accept or reject an aggressive accounting method chosen by the management.

The interaction effect between client type and client retention holds for a subsample analysis of audit managers and partners $(p=0.033)$. This finding does not support the reasoning that higher-ranking auditors are more likely to withstand client retention incentives because they are more aware of the presence of counteracting incentives, such as litigation or 
reputation risks (e.g., Moreno and Bhattacharjee, 2003). Instead, our finding is in line with prior studies showing that auditors of higher rank are sensitive to client retention incentives, because their performance evaluation and compensation often rely strongly on the fee they generate (e.g., Haynes et al., 1998).

--- Insert Table 6 here ---

--- Insert Figure 3 here ---

\subsection{Effects of accountability pressure and client type}

In $\mathrm{H} 2$ we predicted that the influence of client type on an auditor's decision to accept an aggressive accounting method would depend on the level of that auditor's self-reported feelings of accountability. However, our results are not fully consistent with this hypothesis, since the interaction effect of accountability pressure on client type is not significant $(p=$ 0.235; see Table 6). Instead, we find that accountability pressure has a significant main effect on audit opinions ( $p=0.019$; see Table 6 ). This result suggests that auditors risk having their independence impaired not only when they are employed by a management that favours aggressive accounting, but also when they are employed by an oversight board that prefers conservative accounting. One explanation might be that auditors still feel accountable towards the management even if their clients are oversight boards. This accountability feeling might be the present, since oversight boards often play a passive role in resolving contentious accounting issues in reality (Cohen et al., 2010). Therefore, we speculate that as an auditor's client, it is difficult for an oversight board to influence the auditor through accountability pressure.

However, further analyses show that the main effect of accountability pressure is significant for the subsample of lower-rank auditors $(p=0.01)$, but is not significant for the subsample of higher-rank auditors. An explanation for the finding that managers and partners 
judgment is not affected by accountability pressure could be that auditors of higher rank possess greater communication and interpersonal skills (Tan and Libby, 1997).

\section{Conclusion}

In an experiment with professional auditors, we examined the influence of client type on auditors' objectivity as one dimension of auditor independence. We find that auditors' reaction to potential threats to their independence depend on the type of client. First, we find evidence for a difference in behaviour based on client retention incentives. Auditors who are employed by the management and who report high client retention incentives are likely to acquiesce to the management's preferences, but auditors who are employed by supervisory boards and report the same incentives are more likely to resist. Second, we observe that auditors' behaviour does not depend on client type when the auditors feel that they are under high accountability pressure. Specifically, lower-ranking auditors who perceive a high accountability pressure become more lenient towards the management's preferred accounting method in both client conditions. Therefore, these results imply that auditors consider that oversight boards are in charge of making decisions regarding their reappointment or termination, but that auditors still feel accountable to the management. Our findings also provide evidence that client retention incentives and accountability pressure are potential threats to auditors' independence. These threats are distinct from each other, and the effectiveness of potential remedies differs for the two different threats (e.g., Bazerman et al., 2006).

Researchers should consider the following limitations of the experimental design when interpreting the results. First, we measure client retention incentives and accountability pressure instead of randomly varying these factors. We do so because the two threats to auditors' independence are usually intertwined in reality. While this choice ensures the realism of the experimental setting, which is essential in experiments with professional 
auditors, it reduces the ability to draw causal inferences. Second, we make use of the German two-tier system in which the supervisory board takes over the role of the oversight board. Although there is no theoretical reason why our results for a supervisory board as auditors' client should not extend to an audit committee as an auditors' client in a one-tier system, it is an empirical question that we leave for future research. Third, auditors are likely to experience changes in the parties to whom they feel most accountable over their career (Gibbins and Newton, 1994). The static nature of our study precludes the testing how these changes affect auditor' behaviour.

Finally, we note that we contrast the alleged problematic setting in which a management body with incentives that encourage aggressive reporting is the auditor's client with the setting in which a supervisory board with incentives that encourage conservative reporting is the client. Our aim was to reconstruct client types at both typical and strong levels, and by doing so to create a powerful test of the research question: whether client type can influence auditors' independence. One downside to this approach is that it is not possible to infer whether the results are driven by client identity or client preferences. In future research, researchers might attempt to disentangle the two factors by controlling for them separately. 


\footnotetext{
${ }^{1}$ We combine both the audit committees and supervisory boards under the umbrella term "oversight board".

${ }^{2}$ German supervisory board members face mainly internal liability threats with the company itself being the claimant. The overall level of their liability threat is comparable to those of UK non-executive members (Lederer 2006). Given the internal nature of the liability threat and the lack of empirical studies on the subject, we argue that there is no compelling reason why liability threats should not play a role in the context of German private companies.

${ }^{3}$ In total, 84 subjects participated. We excluded 12 participants who indicated IT-auditing, tax consulting or consulting as their main field. Our main results hold, nevertheless, when we include all 84 subjects in our analysis. Among the 72 subjects indicated auditing as their main field, 52 were male and 15 were female auditors; five participants did not indicate their gender.

${ }^{4}$ This applies to stock corporations (Aktiengesellschaften). It also applies to private limited corporations (Gesellschaften mit beschränkter Haftung) with more than 500 employees who are required to form a supervisory board under section 1, paragraph 3 of the One-Third Codetermination Act (Gesetz über die Drittelbeteiligung der Arbeitnehmer im Aufsichtsrat, Drittbeteiligungsgesetz).

${ }^{5}$ Section 52 Gesetz betreffend die Gesellschaften mit beschränkter Haftung, GmbHG (Private Limited Liability Company Act). Furthermore, private limited companies are free to pass corporate bylaws that can even give management the power to directly choose the auditor.

${ }^{6}$ Sections 267, 316 Handelsgesetzbuch (German Commercial Code) requires a company to be audited when two of the following three requirements are fulfilled in two consecutive financial years: more than 50 employees based on an annual average; a balance sheet total of more than $€ 4,840,000$; sales of above $€ 9,680,000$.

${ }^{7}$ An alternative explanation for the higher level of doubt expressed by auditors employed by management could be that the description of the management preferences as favouring aggressive accounting influences auditors towards high fraud risk. If this were the case, then auditors would be expected to be especially doubtful about evidence provided by management. We do not find support for this explanation. Auditors hired by management show the same level of scepticism for evidence provided by management as for evidence provided by other sources. This behaviour is indicated by a nonsignificant interaction effect between client type and a dummy variable for evidence type (one indicates that a piece of evidence is provided by management; and zero otherwise) on evidence evaluation (untabulated). Furthermore, auditors do not differ by client type in their written justifications of their decisions. Auditors hired by the management state even slightly more often that they have relied on evidence provided by management compared to auditors hired by the oversight board (full sample: 39 compared to 32 times; subsample of managers/partners: 14 compared to 11 times).
} 


\section{References}

Abdel-Khalik, A. R. (2002) 'Reforming Corporate Governance post Enron: Shareholder's Board of Trustees and the Auditor.' Journal of Accounting \& Public Policy, 21 (2), pp. 97-103.

Abdolmohammadi, M. J. (1999) 'A Comprehensive Taxonomy of Audit Task Structure, Professional Rank and Decision Aids for Behavioral Research.' Behavioral Research in Accounting, 11, pp. 51-92.

Ai, C., and E. C. Norton. (2003) 'Interaction Terms in Logit and Probit Models.' Economics Letters, 80 (1), pp. 123-129.

Antle, R. (1984) 'Auditor Independence.' Journal of Accounting Research, 22 (1), pp. 1-20.

Bamber, E. M., and V. M. Iyer. (2007) 'Auditors' Identification with Their Clients and Its Effect on Auditors' Objectivity.' Auditing: A Journal of Practice \& Theory, 26 (2), pp. $1-24$.

Bazerman, M. H., G. Loewenstein, and D. A. Moore. (2002) 'Why Good Accountants Do Bad Audits.' Harvard Business Review, 80 (11), pp. 96-103.

Bazerman, M. H., D. A. Moore, P. E. Tetlock, and L. Tanlu. (2006) 'Reports of Solving the Conflicts of Interest in Auditing are Highly Exaggerated.' Academy of Management Review, 31 (1), pp. 43-49.

Bazerman, M. H., K. P. Morgan, and G. F. Loewenstein. (1997) 'The Impossibility of Auditor Independence.' Sloan Management Review, 38 (4), pp. 89-94.

Blay, A. D. (2005) 'Independence Threats, Litigation Risk, and the Auditor's Decision Process.' Contemporary Accounting Research, 22 (4), pp. 759-789.

Boiney, L. G., J. Kennedy, and P. Nye. (1997) 'Instrumental Bias in Motivated Reasoning: More When More Is Needed.' Organizational Behavior \& Human Decision Processes, 72 (1), pp. 1-24.

Bonner, S. E. (2007). Judgment and Decision Making in Accounting (Englewood, NJ: Prentice Hall).

Brazel, J. F., C. P. Agoglia, and R. C. Hatfield. (2004) 'Electronic versus Face-to-Face Review: The Effects of Alternative Forms of Review on Auditors' Performance.' The Accounting Review, 79 (4), pp. 949-966.

Buchman, T. A., P. E. Tetlock, and R. O. Reed. (1996) 'Accountability and Auditors' Judgments about Contingent Events.' Journal of Business Finance \& Accounting, 23 (3), pp. 379-398.

Carcello, J. V., D. R. Hermanson, and Z. S. Ye. (2011) 'Corporate Governance Research in Accounting and Auditing: Insights, Practice Implications, and Future Research Directions.' Auditing: A Journal of Practice \& Theory, 30 (3), pp. 1-31.

Chang, C. J., and N.-C. R. Hwang. (2003) 'The Impact of Retention Incentives and Client Business Risks on Auditors' Decisions Involving Aggressive Reporting Practices.' Auditing: A Journal of Practice \& Theory, 22 (2), pp. 207-218.

Chen, K. Y., and Z. Jian. (2007) 'Audit Committee, Board Characteristics, and Auditor Switch Decisions by Andersen's Clients.' Contemporary Accounting Research, 24 (4), pp. 1085-1117.

Chen, S., D. Shechter, and S. Chaiken. (1996) 'Getting at the Truth or Getting Along: Accuracy- Versus Impression-Motivated Heuristic and Systematic P.' Journal of Personality and Social Psychology, 71 (2), pp. 262-275.

Cohen, J. R., G. Krishnamoorthy, and A. Wright. (2010) 'Corporate Governance in the PostSarbanes-Oxley Era: Auditor Experiences.' Contemporary Accounting Research, 27 (3).

DeAngelo, L. E. (1981) 'Auditor Independence, "Low Balling", and Disclosure Regulation.' Journal of Accounting \& Economics, 3 (2), pp. 112-127.

DeZoort, F. T., and A. T. Lord. (1997) 'A Review and Synthesis of Pressures Effects in Accounting.' Journal of Accounting Literature, 16, pp. 28-85. 
DeZoort, T., P. Harrison, and M. Taylor. (2006) 'Accountability and Auditors' Materiality Judgments: The Effects of Differential Pressure Strength on Conservatism, Variability, and Effort.' Accounting, Organizations \& Society, 31 (4/5), pp. 373-390.

Dopuch, N., R. R. King, and R. Schwartz. (2001) 'Independence in Appearance and in Fact: An Experimental Investigation.' Contemporary Accounting Research, 20 (1), pp. 79114.

Dye, R. A. (1991) 'Informationally Motivated Auditor Replacement.' Journal of Accounting \& Economics, 14 (4), pp. 348-374.

European Union. (2006) 'Directive 2006/43/EC on Statutory Audit of Annual Accounts and Consolidated Accounts and amending Council Directives 78/660/EEC and 83/349/EEC.' Official Journal of the European Union L 157 pp. 87-106.

Financial Reporting Council. 2008. The Combined Code on Corporate Governance.

Financial Services Authority. 2009. 2009/42 Supervision Manual (Controlled Functions).

Gassen, J., and H. A. Skaife. (2009) 'Can Audit Reforms Affect the Information Role of Audits? Evidence from the German Market.' Contemporary Accounting Research, 26 (3), pp. 867-898.

Gendron, Y., J. Bédard, and M. Gosselin. (2004) 'Getting Inside the Black Box: A Field Study of Practices in "Effective" Audit Committees.' Auditing: A Journal of Practice \& Theory, 23 (1), pp. 153-171.

German Federal Parliament. (1998) 'German Corporate Control and Transparency Act.' BGBI I, pp. 786-794.

Gibbins, M., and J. D. Newton. (1994) 'An Empirical Exploration of Complex Accountability in Public Accounting.' Journal of Accounting Research, 32 (2), pp. 165-186.

Gibbins, M., S. Salterio, and A. Webb. (2001) 'Evidence About Auditor-Client Management Negotiation Concerning Client's Financial Reporting.' Journal of Accounting Research, 39 (3), pp. 535-563.

Gramling, A. A. (1999) 'External Auditors' Reliance on Work Performed by Internal Auditors: The Influence of Fee Pressure on This Reliance Decision.' Auditing: A Journal of Practice \& Theory, 18 (2), pp. 117-135.

Hackenbrack, K., and M. W. Nelson. (1996) 'Auditors' Incentives and Their Application of Financial Accounting Standards.' The Accounting Review, 71 (1), pp. 43-59.

Haynes, C. M., J. G. Jenkins, and S. R. Nutt. (1998) 'The Relationship Between Client Advocacy and Audit Experience: An Exploratory Analysis.' Auditing: A Journal of Practice \& Theory, 17 (2), pp. 88-104.

Hoi, C.-K., A. Robin, and D. Tessoni. (2007) 'Sarbanes-Oxley: Are Audit Committees up to the Task?' Managerial Auditing Journal, 22 (3), pp. 255-267.

Joe, J. R. (2003) 'Why Press Coverage of a Client Influences the Audit Opinion.' Journal of Accounting Research, 41 (1), pp. 109-133.

Kadous, K., S. J. Kennedy, and M. E. Peecher. (2003) 'The Effect of Quality Assessment and Directional Goal Commitment on Auditors' Acceptance of Client-Preferred Accounting Methods.' The Accounting Review, 78 (3), pp. 759-778.

Lederer, P. (2006) 'A Comparative Analysis of the Liability of Non-executive Directors in the UK and of Members of the Supervisory Board in Germany.' European Business Law Review, 17 (6), pp. 1575-1613.

Lee, C.-W. J., and Z. Gu. (1998) 'Low Balling, Legal Liability and Auditor Independence.' The Accounting Review, 73 (4), pp. 533-555.

Lennox, C. (2000) 'Do Companies Successfully Engage in Opinion-Shopping? Evidence from the UK.' Journal of Accounting \& Economics, 29 (3), pp. 321-337.

Lerner, J. S., and P. E. Tetlock. (1999) 'Accounting for the Effects of Accountability.' Psychological Bulletin, 125 (2), pp. 255-275. 
Leuz, C., and J. Wüstemann. (2004). 'The Role of Accounting in the German Financial System', in J. P. Krahnen and R. H. Schmidt (Eds) The German Financial System, pp. 450-481. (Oxford: Oxford University Press).

Magee, R. P., and M.-C. Tseng. (1990) 'Audit Pricing and Independence.' The Accounting Review, 65 (2), pp. 315-336.

Mayhew, B. W., and J. E. Pike. (2004) 'Does Investor Selection of Auditors Enhance Auditor Independence?' The Accounting Review, 79 (3), pp. 797-822.

Moore, D. A., P. E. Tetlock, L. Tanlu, and M. H. Bazerman. (2006) 'Conflicts of Interest and the Case of Auditor Independence: Moral Seduction and Strategic Issue Cycling.' Academy of Management Review, 31 (1), pp. 10-29.

Moreno, K., and S. Bhattacharjee. (2003) 'The Impact of Pressure from Potential Client Business Opportunities on the Judgments of Auditors across Professional Ranks.' Auditing: A Journal of Practice \& Theory, 22 (1), pp. 13-28.

Nelson, M. W., J. A. Elliott, and R. L. TarpIey. (2002) 'Evidence from Auditors about Managers' and Auditors' Earnings Management Decisions.' The Accounting Review, 77 (4), pp. 175-202.

Nelson, M. W., and W. R. Kinney. (1997) 'The Effect of Ambiguity on Loss Contingency Reporting Judgements.' The Accounting Review, 72 (2), pp. 257-274.

Peecher, M. E. (1996) 'The Influence of Auditors' Justification Processes on Their Decisions: A Cognitive Model and Experimental Evidence.' Journal of Accounting Research, 34 (1), pp. 125-140.

Pomeroy, B. (2010) 'Audit Committee Member Investigation of Significant Accounting Decisions.' Auditing: A Journal of Practice \& Theory, 29 (1), pp. 173-205.

Pomeroy, B., and D. B. Thornton. (2008) 'Meta-analysis and the Accounting Literature: The Case of Audit Committee Independence and Financial Reporting Quality.' European Accounting Review, 17 (2), pp. 305-330.

Ricchiute, D. N. (1999) 'The Effect of Audit Seniors' Decisions on Working Paper Documentation and on Partners' Decisions.' Accounting, Organizations \& Society, 24 (2), pp. 155-171.

Salterio, S., and L. Koonce. (1997) 'The Persuasiveness of Audit Evidence: The Case of Accounting Policy Decisions.' Accounting, Organizations \& Society, 22 (6), pp. 573587.

Sanchez, M. H., C. P. Agoglia, and R. C. Hatfield. (2007) 'The Effect of Auditors' Use of a Reciprocity-Based Strategy on Auditor-Client Negotiations.' The Accounting Review, 82 (1), pp. 241-263.

Schlenker, B. R. (1980). Impression Management: The Self-concept Social Identity and Interpersonal Relations. (Belmont, CA: Brooks-Cole).

Schlenker, B. R., T. W. Britt, J. Pennington, R. Murphy, and K. Doherty. (1994) 'The Triangle Model of Responsibility.' Psychological Review, 101 (4), pp. 621-652.

Schöndube-Pirchegger, B., and J. R. Schöndube. (2010) 'On the Appropriateness of Performance-Based Compensation for Supervisory Board Members - An Agency Theoretic Approach.' European Accounting Review, 19 (4), pp. 817-835.

SEC. 2003. Final Rule: Standards Relating to Listed Company Audit Committees, Release No. 33-8220: SEC Washington DC.

Shadish, W. R., T. D. Cook, and D. T. Campbell. (2002). Experimental and QuasiExperimental Designs for Generalized Causal Inference. (Boston, MS \& New York, NY: Houghton Mifflin Company).

Tan, H.-T., and R. Libby. (1997) 'Tacit Managerial versus Technical Knowledge as Determinants of Audit Expertise in the Field.' Journal of Accounting Research, 35 (1), pp. 97-113. 
Taylor, M. H., F. T. DeZoort, E. Munn, and M. W. Thomas. (2003) 'A Proposed Framework Emphasizing Auditor Reliability over Auditor Independence.' Accounting Horizons, 17 (3), pp. 257-266.

Tetlock, P. E. (1985) 'Accountability: The Neglected Social Context of Judgment and Choice.' Research in Organizational Behavior, 7, pp. 297-332.

Theisen, M. R. (2007). Information und Berichterstattung des Aufsichtsrats (Supervisory board: information rights and reporting duties). 4 ed. (Stuttgart: Schäffer-Poeschel).

Trompeter, G. (1994) 'The Effect of Partner Compensation Schemes and Generally Accepted Accounting Principles on Audit Partner Judgment.' Auditing: A Journal of Practice \& Theory, 13 (2), pp. 56-68.

Turner, C. W. (2001) 'Accountability Demands and the Auditor's Evidence Search Strategy: The Influence of Reviewer Preferences and the Nature of the Response (Belief vs. Action).' Journal of Accounting Research, 39 (3), pp. 683-706.

Tversky, A. (1972) 'Elimination by Aspects: A Theory of Choice.' Psychological Review, 79 (4), pp. 281-299.

Wilks, T. J. (2002) 'Predecisional Distortion of Evidence as a Consequence of Real-Time Audit Review.' The Accounting Review, 77 (1), pp. 51-71. 
Figure 1. Procedure

\begin{tabular}{|l|}
\hline Part 1 \\
Background information \\
Random assignment of \\
auditors to client condition \\
Information on clients' \\
preferences \\
Announcement that one in \\
eight auditors will have a \\
client meeting at the end of \\
the study in which they will \\
need to defend their \\
judgments. \\
Framing questions about the \\
setting \\
Treatment variable \\
Management favouring \\
aggressive accounting \\
Supervisory board \\
favouring conservative \\
accounting
\end{tabular}

\section{Part 2}

\section{Accounting cases}

Information on preliminary

financial statement

Stepwise presentation of five pieces of evidence

Questions on auditors' judgments and decisions.

Dependent variables

Audit opinion

Measurement

GAAP conformance

Audit evidence

(See Table 2 for details)

\section{Part 3}

\section{Questionnaire}

Post-experiment questionnaire on demographic data and threats to auditors' independence

Measured variables

Client retention incentives (CRI) Accountability pressure (AP) (see Table 3 for details) 
Figure 2. Empirical path model of the effects of client type

\section{$\underline{\text { Link } 1}$}

Full sample: $-5.71 * * *$

Subsample: $-4.78 * * *$

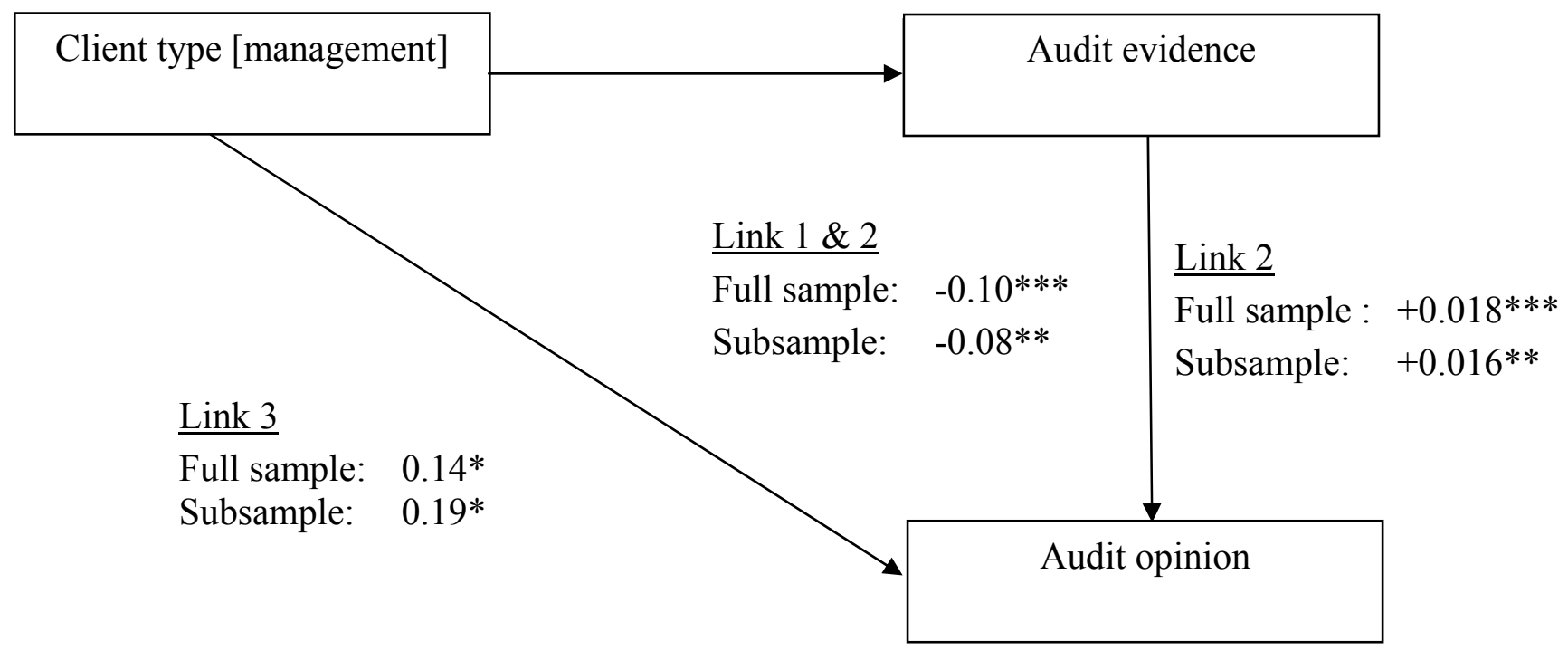

The figure shows the results of a path analysis designed to simultaneously test the direct effect (Link 3 ) and indirect effect (Links 1 and 2) of client type on audit opinion for both the full sample and the subsample of managers/partners. The figure shows the nonstandardized path coefficient next to each link. The model also controls for the effects of case (indicator variable for case study type [provisions; receivables]; not shown in the figure) on audit evidence (full sample $=4.30^{* * *}$; subsample $=7.07^{* * *}$ ) and on audit opinion (full sample $=0.32^{* * *}$; subsample $=0.44^{* * *}$ ). The goodness of fit of the model is excellent (full sample: Chi-square $=0.007 ; \mathrm{df}=3 ; p=1, \mathrm{n}=141$; subsample: Chi-square $=0.003 ; \mathrm{df}=3 ; p=1, \mathrm{n}=58$ ).

Client type: management favouring aggressive accounting compared toa supervisory board favouring conservative accounting.

Audit evidence: evaluation of consistency of audit evidence and firm's accounting method [-25 to +25$]$. Audit opinion: type of audit opinion issued [1: unqualified opinion; 0: qualified or adverse opinion].

$* * * / * * * *$ : significant at the $1 \%, 5 \%$, or $10 \%$ level (two-tailed). 
Figure 3. Interactive effect of client type and client retention incentives (CRI) on the audit opinion

Panel A: Full sample

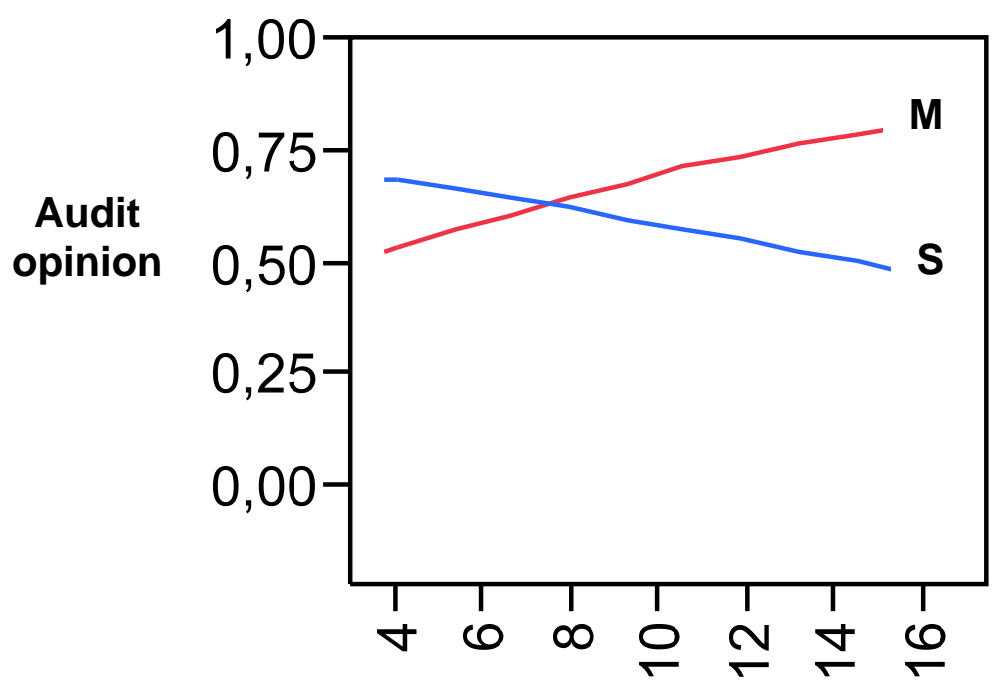

CRI

Panel B: Subsample of managers/partners

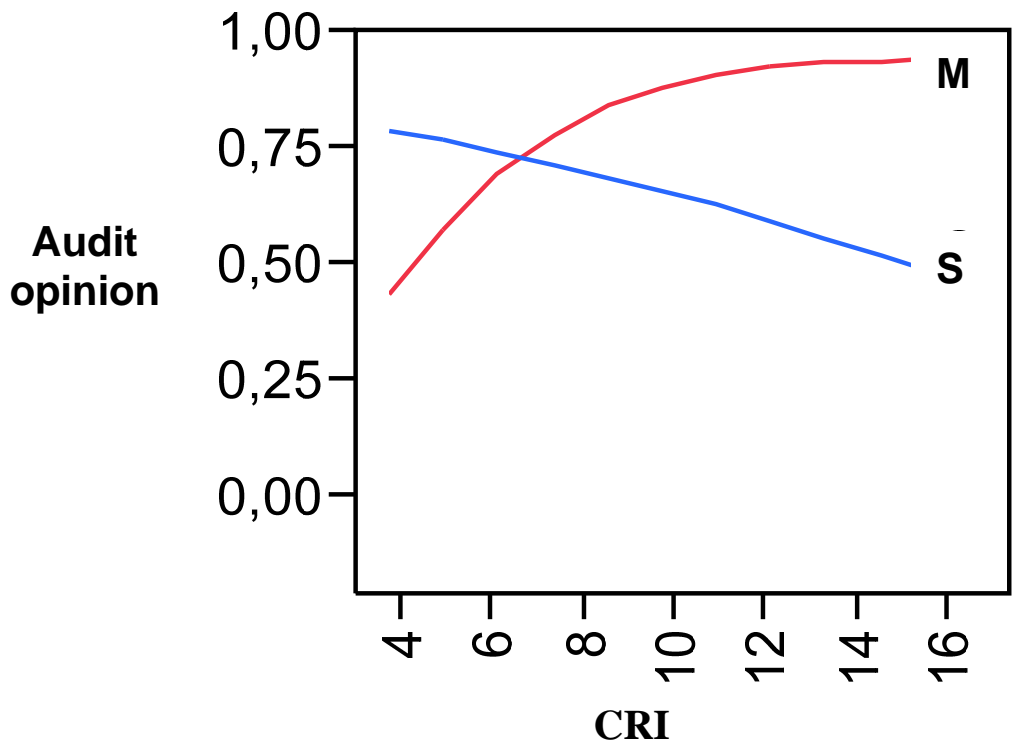

This figure shows the interaction effect of client retention incentives (CRI) and client type [M vs. S] on the audit opinion. See Table 6 for the underlying regression model.

Client type: management $[\mathrm{M}]$ favouring aggressive accounting compared to a supervisory board $[\mathrm{S}]$ favouring conservative accounting.

Audit opinion: type of audit opinion issued [1: unqualified opinion; 0: qualified or adverse opinion].

Client retention incentives (CRI): combined measure of the assessed threat of losing the client and other auditors' likely reaction to such a threat. 
Table 1. Number of years of participants' auditing experience by auditors' rank.

\begin{tabular}{lcccccc}
\hline \hline & $\mathbf{n}$ & $\mathbf{1 Q}$. & Med. & $\mathbf{3 Q}$. & Mean & SD \\
\hline Staff & 21 & 2 & 3 & 4.5 & 3.28 & 1.27 \\
\hline Seniors & 18 & 3.9 & 4 & 6 & 6.65 & 6.60 \\
\hline Managers & 18 & 9 & 11.5 & 16.5 & 13.78 & 7.64 \\
\hline Partners & 11 & 14.5 & 16 & 24.5 & 19.00 & 8.75 \\
\hline \hline Overall & 68 & 2 & 5 & 36 & 9.50 & 8.47 \\
\hline
\end{tabular}

Reported is the maximum number of available observations. 
Table 2. Dependent variables.

\begin{tabular}{|c|c|c|c|}
\hline $\begin{array}{l}\text { Type of } \\
\text { task }\end{array}$ & $\begin{array}{l}\text { Dependent } \\
\text { variable }\end{array}$ & Elicitation method & Characteristics \\
\hline \multirow{3}{*}{$\begin{array}{l}\text { Decision/ } \\
\text { action } \\
\text { task }\end{array}$} & $\begin{array}{l}\text { Audit } \\
\text { opinion } \\
\text { (primary } \\
\text { dependent } \\
\text { variable) }\end{array}$ & $\begin{array}{l}\text { "What audit opinion } \\
\text { would you issue?" }\end{array}$ & $\begin{array}{l}\text { Coding of audit opinions: } \\
\text { - unqualified opinion }(=1) \\
\text { - qualified or adverse opinion }(=0)\end{array}$ \\
\hline & & "In your opinion, & $\begin{array}{l}\text { Adjustments as the difference of auditor's } \\
\text { measurement and the measurement in the } \\
\text { preliminary financial statement. }\end{array}$ \\
\hline & $\begin{array}{l}\text { Measure- } \\
\text { ment }\end{array}$ & $\begin{array}{l}\text { What value should be } \\
\text { reported in the } \\
\text { financial statement } \\
\text { under German } \\
\text { GAAP?" }\end{array}$ & $\begin{array}{l}\text { Possible ranges for adjustments: } \\
+15 \text { to }-110 \text { Mio. } € \text { for the provision case, } \\
+10 \text { to }-115 \text { Mio. } € \text { for the receivables case. } \\
\text { (Negative values indicate that auditor's } \\
\text { measurement would have an income } \\
\text { decreasing effect.) }\end{array}$ \\
\hline \multirow{2}{*}{$\begin{array}{l}\text { Judgment/ } \\
\text { belief task }\end{array}$} & $\begin{array}{l}\text { GAAP } \\
\text { conform- } \\
\text { ance }\end{array}$ & $\begin{array}{l}\text { "Is the accounting } \\
\text { method used in } \\
\text { conformance with } \\
\text { German GAAP?" }\end{array}$ & $\begin{array}{l}\text { 11-point Likert scale ranging from } \\
0 \text { (= not in conformance with GAAP) to } \\
10 \text { (= fully in conformance with GAAP). }\end{array}$ \\
\hline & $\begin{array}{l}\text { Audit } \\
\text { evidence }\end{array}$ & $\begin{array}{l}\text { How do you evaluate } \\
\text { this piece of } \\
\text { evidence? }\end{array}$ & $\begin{array}{l}\text { 11-point Likert scale ranging from } \\
-5 \text { (= fully inconsistent) to } \\
+5 \text { (= fully consistent) for each piece. } \\
-25 \text { to }+25 \text { aggregated over all five pieces of } \\
\text { each case. }\end{array}$ \\
\hline
\end{tabular}


Table 3. Independent variables

\begin{tabular}{|c|c|c|}
\hline & Elicitation method & Classification \\
\hline Client type & Random assignment & $\begin{array}{l}\text { Client: } \\
\text { management favouring aggressive } \\
\text { reporting ( } 37 \text { auditors); } \\
\text { supervisory board favouring } \\
\text { conservative reporting ( } 35 \text { auditors) }\end{array}$ \\
\hline \multirow[t]{2}{*}{$\begin{array}{l}\text { Client } \\
\text { retention } \\
\text { incentives } \\
\text { (CRI) }\end{array}$} & $\begin{array}{l}\text { Risk of losing the client } \\
\text { "In your experience, what is the } \\
\text { proportion of audits where the } \\
\text { auditor is likely to be replaced in the } \\
\text { case of dissent between the auditor } \\
\text { and the management [supervisory } \\
\text { board]?" } \\
11-\text { point Likert scale ranging from } \\
0(0 \%) \text { to } 10(100 \%) \text {. } \\
\text { Mean (SD) }=3.61(2.38)\end{array}$ & $\begin{array}{l}\text { Client retention incentives }(\mathrm{CRI})= \\
\text { risk of losing the client }+ \\
\text { auditors' reaction to the risk of } \\
\text { losing the client }\end{array}$ \\
\hline & $\begin{array}{l}\text { Reaction to the risk of losing the } \\
\text { client } \\
\text { "Do you agree to the following } \\
\text { statement: 'In this study, auditors are } \\
\text { more willing to adjust their judgment } \\
\text { to the accounting method preferred } \\
\text { by the audited company when they } \\
\text { have to fear losing the client."” } \\
\text { 7-point Likert scale ranging from } \\
1 \text { (= fully disagree) to } 7 \text { (= fully } \\
\text { agree). } \\
\text { Mean (SD) }=4.50(1.67)\end{array}$ & \\
\hline \multirow[t]{2}{*}{$\begin{array}{l}\text { Account- } \\
\text { ability } \\
\text { pressure } \\
\text { (AP) }\end{array}$} & $\begin{array}{l}\text { Conflict avoidance } \\
\text { "In this study, I had the intention to } \\
\text { avoid conflict in the prospective } \\
\text { meeting with the management } \\
\text { [supervisory board]" } \\
\text { 7-point Likert scale ranging from } \\
1 \text { (= fully disagree) to } 7 \text { (= fully } \\
\text { agree). } \\
\text { Mean (SD) }=2.80(1.90)\end{array}$ & $\begin{array}{l}\text { Accountability pressure }(\mathrm{AP})= \\
\text { conflict avoidance }+ \\
\text { personal responsibility }\end{array}$ \\
\hline & $\begin{array}{l}\text { Personal responsibility } \\
\text { "I would persist on my evaluations } \\
\text { [stated in this study] even if other } \\
\text { colleagues from my audit firm } \\
\text { disagreed." } \\
\text { 7-point Likert scale ranging from } \\
1 \text { (= fully disagree) to } 7 \text { (= fully } \\
\text { agree). } \\
\text { Mean (SD) }=3.37 \text { (1.56) }\end{array}$ & \\
\hline
\end{tabular}


Table 4. Descriptive statistics and relation between independent variables

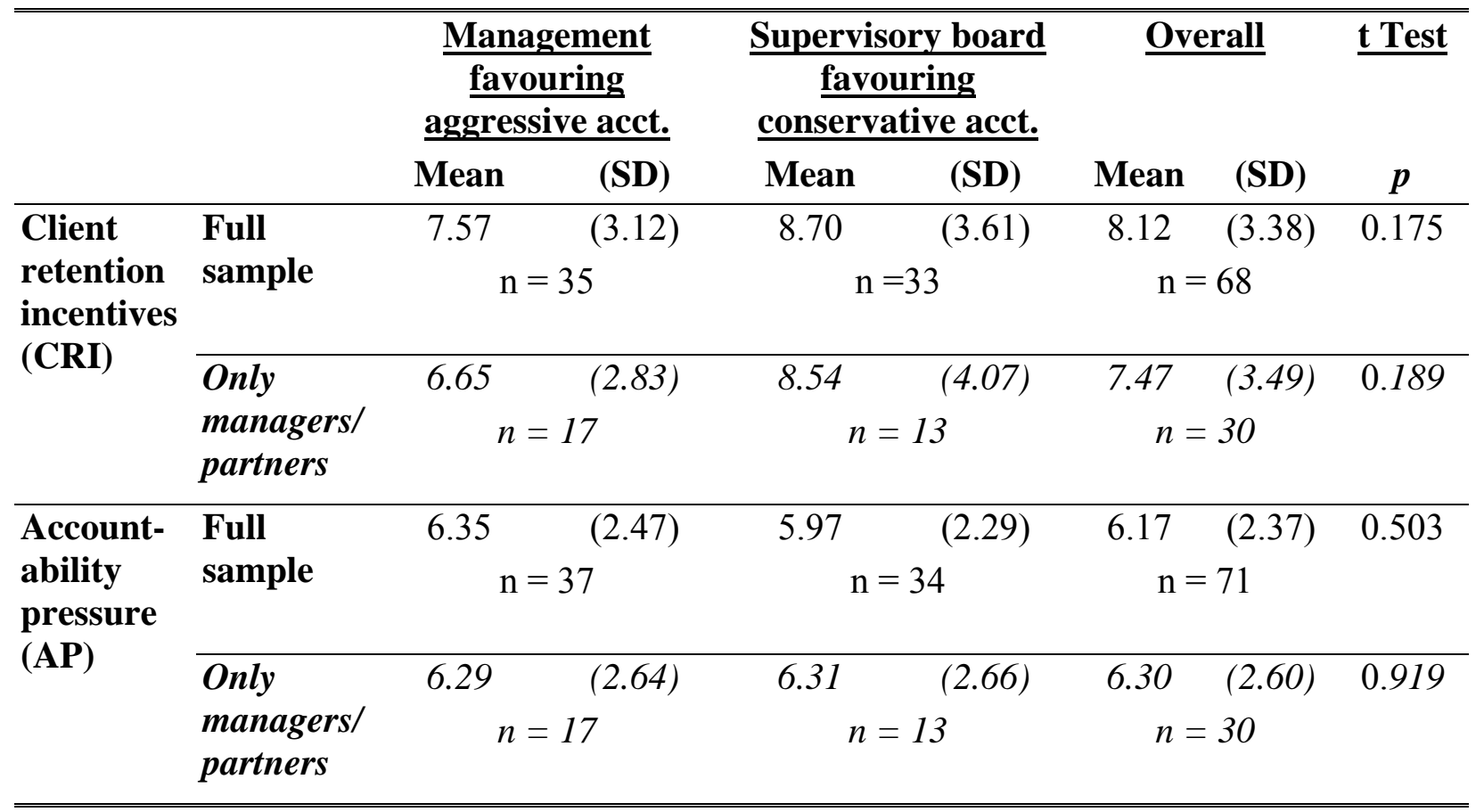

The table shows that the variation of client type has no statistically significant effects on the measured variables. Further tests show that CRI and AP are not statistically significantly correlated in the full sample $(\rho=0.11 ; p$ value $=0.386)$, and are marginally significantly correlated in the subsample of managers/partners $(\rho=0.36 ; p$ value $=0.051)$.

Client retention incentives (CRI): combined measure of the assessed threat of losing the client and other auditors' likely reaction to such a threat.

Accountability pressure (AP): combined measure of the assessed level of conflict avoidance and feelings of responsibilities. 
Table 5. Descriptive statistics of dependent variables by client type.

\begin{tabular}{|c|c|c|c|c|c|c|}
\hline & & $\begin{array}{c}\frac{\text { Management }}{\text { favouring }} \\
\text { aggressive acct. }\end{array}$ & $\begin{array}{c}\text { Supervisory } \\
\text { board favouring } \\
\text { conservative acct. }\end{array}$ & Overall & $\underline{p}^{+}$ & \\
\hline & & Mean & Mean & Mean & & \\
\hline \multirow{4}{*}{$\begin{array}{l}\text { Audit } \\
\text { opinion }\end{array}$} & \multirow[t]{2}{*}{ Full sample } & $(0.50)$ & $(0.50)$ & $0.47 \quad(0.50)$ & 0.608 & \\
\hline & & $\mathrm{n}=72$ & $\mathrm{n}=69$ & $\mathrm{n}=141$ & & \\
\hline & \multirow{2}{*}{$\begin{array}{l}\text { Only manager/ } \\
\text { partner }\end{array}$} & $0.53 \quad(0.50)$ & $0.42 \quad(0.50)$ & $0.48 \quad(0.50)$ & 0.339 & \\
\hline & & $\mathrm{n}=32$ & $\mathrm{n}=26$ & $\mathrm{n}=58$ & & \\
\hline \multirow{4}{*}{$\begin{array}{l}\text { Measure- } \\
\text { ment }\end{array}$} & \multirow[t]{2}{*}{ Full sample } & $-41.3 \quad(35.4)$ & $-38.3 \quad(37.5)$ & $39.8 \quad(36.3)$ & 0.521 & \\
\hline & & $\mathrm{n}=72$ & $\mathrm{n}=69$ & $\mathrm{n}=141$ & & \\
\hline & \multirow{2}{*}{$\begin{array}{l}\text { Only manager/ } \\
\text { partner }\end{array}$} & $(38.9)$ & $-43.7 \quad(38.5)$ & $38.6 \quad(38.7)$ & 0.262 & \\
\hline & & $\mathrm{n}=32$ & $\mathrm{n}=26$ & $\mathrm{n}=58$ & & \\
\hline \multirow{4}{*}{$\begin{array}{l}\text { GAAP } \\
\text { conform- } \\
\text { ance }\end{array}$} & \multirow[t]{2}{*}{ Full sample } & $(3.07)$ & $(3.11)$ & $4.25 \quad(3.16)$ & 0.012 & $* *$ \\
\hline & & $\mathrm{n}=73$ & $\mathrm{n}=69$ & $\mathrm{n}=142$ & & \\
\hline & \multirow{2}{*}{$\begin{array}{l}\text { Only manager/ } \\
\text { partner }\end{array}$} & $(3.14)$ & $(3.61)$ & $4.53 \quad(3.33)$ & 0.653 & \\
\hline & & $\mathrm{n}=33$ & $\mathrm{n}=25$ & $\mathrm{n}=58$ & & \\
\hline \multirow{4}{*}{$\begin{array}{l}\text { Audit } \\
\text { evidence }\end{array}$} & \multirow[t]{2}{*}{ Full sample } & $-5.55 \quad(7.29)$ & $(8.69)$ & $-2.76 \quad(8.48)$ & 0.026 & $* *$ \\
\hline & & $\mathrm{n}=74$ & $\mathrm{n}=70$ & $\mathrm{n}=144$ & & \\
\hline & \multirow{2}{*}{$\begin{array}{l}\text { Only manager/ } \\
\text { partner }\end{array}$} & $(8.95)$ & $(8.55)$ & $-4.28 \quad(8.51)$ & $<0.001$ & $* * *$ \\
\hline & & $\mathrm{n}=34$ & $\mathrm{n}=26$ & $\mathrm{n}=60$ & & \\
\hline
\end{tabular}

This table shows that auditors employed by a management that favours aggressive accounting are more sceptical in judgment tasks (GAAP conformance, audit evidence) than are auditors employed by a supervisory board that favours conservative accounting, but not in decision tasks (measurement, audit opinion).

Audit opinion: type of audit opinion issued [1: unqualified opinion; 0: qualified or adverse opinion]. Measurement: effects of applying auditor's measurement decision on firm's income [-110/115 to $+10 / 15]$.

GAAP conformance: evaluation of the conformance of firm's accounting method with GAAP [1 to 11].

Audit evidence: evaluation of consistency of audit evidence and firm's accounting method [ -25 to +25$]$.

+ Test is on the effects of client type including an indicator variable for case version as a control.

$* * * / * * / *$ : significant at the $1 \%, 5 \%$, or $10 \%$ level. 
Table 6. Logistic regression analyses on the audit opinion

\begin{tabular}{lcc}
\hline Term & (1) Full sample & $\begin{array}{c}\text { (2) Subsample of } \\
\text { managers/partners }\end{array}$ \\
\hline Intercept & -1.10 & -1.86 \\
& $(0.36)$ & $(0.69)$ \\
& {$[0.002]$} & {$[0.007]$} \\
\hline Client type [management] & 0.33 & 0.98 \\
& $(0.40)$ & $(0.74)$ \\
\hline Client retention incentives (CRI) & {$[0.407]$} & {$[0.187]$} \\
& -0.08 & -0.13 \\
& $(0.08)$ & $(0.13)$ \\
CRI * client [management] & {$[0.324]$} & {$[0.341]$} \\
& $\mathbf{0 . 2 1}$ & $\mathbf{0 . 5 8}$ \\
& $\mathbf{( 0 . 1 2 )}$ & {$[\mathbf{0 . 0 3 3}$} \\
\hline Accountability pressure (AP) & {$[\mathbf{0 . 0 8 3}$} & 0.10 \\
& $\mathbf{0 . 3 1}$ & $(0.20)$ \\
& $\mathbf{( 0 . 1 3 )}$ & {$[0.616]$} \\
\hline AP * client [management] & {$[\mathbf{0 . 0 1 9}$} & -0.43 \\
& -0.20 & $(0.31)$ \\
& $(0.17)$ & {$[0.160]$} \\
\hline Case [provision] & {$[0.235]$} & 2.95 \\
& 1.79 & {$[0.75)$} \\
& $(0.40)$ & {$[<0.001]$} \\
\hline
\end{tabular}

This table shows that the client type interacts with perceived client retention incentives (H1). The table shows the coefficients (standard errors) [p-values]; estimates are for log ratios of 1/0 of audit opinion [unqualified opinion vs. qualified and adverse opinion]; significant treatment effects are in bold.

(1) Full sample: R2 (Pseudo) $=0.17 ; \mathrm{n}=134$

(2) Subsample of managers/partners: R2 (Pseudo) $=0.32 ; \mathrm{n}=58$

Ai and Norton (2003) suggest that p-values of interaction terms in logit models might be biased. Using their suggested correction for this bias yields the following $\mathrm{p}$-values for the interaction between client retention incentives and client type: Model 1: $\mathrm{p}($ corr. $)=0.091$; Model 2: $\mathrm{p}($ corr. $)=0.083$.

Client type: management favouring aggressive accounting compared to a supervisory board favouring conservative accounting.

Client retention incentives (CRI): combined measure of the assessed threat of losing the client and other auditors' likely reaction to such a threat.

Accountability pressure (AP): combined measure of the assessed level of conflict avoidance and feelings of responsibilities.

Case: indicator variable for type of accounting case [provision; receivables]. 